\title{
Musical Totem: A Collaborative Composition Methodology During the COVID-19 Pandemic
}

\author{
Víctor Manuel Rubio Carrillo, David Echeverría-Valencia, \\ Eliana Sofía Vaca, and Sebastián López Prado
}

\begin{abstract}
As part of the Action Research Network of the Americas, the Musical Learning Community is a collaborative group, founded during the COVID-19 global pandemic, that has brought together musicians, artists, and educators to generate shared experiences. As members of this community, we explore new ways for collaborative music-making. Through creative, cultural, and conceptual influences, the idea of the Musical Totem emerged as a collaborative music composition methodology to transcend geographical distancing. We sought interpretative freedom by adopting methods of the surrealist technique Cadavre Exquis (Exquisite Corpse) while relying on the rich concept of totems to find thematic material and set compositional parameters. The process was carried out using arts-based and autoethnographic research approaches, which provided insights into our creative musical responses and remote collaborative working processes. This endeavor showed us that symbolism can provide compositional and performative challenges and that, as a methodology, the Musical Totem can create freedom and constraints depending on the musician, the conceptual influences, and the instrumentation. We also learned that engaging in a collaborative music-making process led to increased community bonding through shared creative expression.
\end{abstract}

Víctor Manuel Rubio Carrillo (vmr64@miami.edu) is currently undergoing Ph.D. studies in music education at the University of Miami and is the founder and conductor of the Musical Learning Community (mlc.cam.arna@gamil.com). David Echeverría-Valencia is a faculty member at Universidad de los Hemisferios. He is founder of La Liga de la Música and works as academic coordinator of the Musical Learning Community. Eliana Sofía Vaca is a violinist at the Orquesta Ciudad de Quito, and currently works as executive coordinator of the Musical Learning Community. Sebastián López Prado is a musician teaching artist from Ecuador and works as faculty at Colegio de Artes Musicales Luis Humberto Salgado Torres.

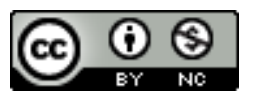

This work is licensed under a Creative Commons Attribution-NonCommercial 4.0 International License. 


\section{Examining the Impact of COVID-19 on Music Communities}

By February 2020, the destructive effects of the global COVID-19 pandemic had already hit the Americas. Many musical, educational, and research activities ceased; however, virtual communications helped to sustain some new initiatives during this time. That was the case for the Music Learning Community (MLC), ${ }^{1}$ which, during the pandemic, was proposed as one of the Action Research Communities (ARCs) within the Action Research Network of the Americas (ARNA). ${ }^{2}$ The MLC held its inaugural meeting in April 2020, bringing together musicians, artists, and educators to generate shared experiences. As members of this network, we work together as a virtual community, and through collective learning, we have fostered our natural tendencies to grow and create.

During the pressing times of the pandemic, the Canadian Association of Music Libraries, Archives and Documentation Centres (CAML) raised the concern that music activities at all levels were struggling. ${ }^{3}$ Given the interruption in music creation, communication, preservation, and investigation, how would music professionals at all levels respond? Shifts in modes of writing and sharing meant that musicians needed to rely on virtual platforms to promote and archive their material. Music education became mediated by digital life. Under these conditions, how were musical communities addressing the impact of COVID-19 in their performance, production, dissemination, and preservation of artistic work? In this paper, we discuss how the MLC examined its musical activity, resulting in a new virtual collaborative composition methodology amidst the ongoing pandemic - the Musical Totem.

\section{Contemporary Music and the Musical Learning Community}

Four members of the MLC participated in this study. The four of us share not only a common musical background but also a birthplace. We were born in the highlands of the Andes in Ecuador, where we all obtained our music degrees in contemporary music. Despite this, our musical practices are contrasting. David specializes as a jazz drummer and contemporary composer. Sebastián is a popular music guitarist. Sofía has evolved as a classical violinist and orchestral performer, and Víctor has trained as a rock-tenor and classical guitarist. It was intriguing for us to see what would come out of this formation, being our first experience creating music together.

In the context of contemporary music from European and American traditions, we have seen that many current musical composition practices have deserted tonality as means to explore new timbres. ${ }^{4}$ Composers have also found new ways of liberating traditions by leaving behind structures of musical form. The openness provided by relinquishing form has provided performers with an

\footnotetext{
${ }^{1}$ For more information on the Musical Learning Community, visit https://www.mlc-cam.info/

${ }^{2}$ For more information on the Action Research Network of the Americas, visit https://arnawebsite.org/

3 "Call for Contributions: Special Issue on the Impact of Covid-19 on Music Communities," CAML Review, accessed May 6, 2021, https://www.caml-acbm.org/en/publication/.

${ }^{4}$ Martin Link, "Contemporary Music and Its Challenges for Music Theory," Harmonia: Journal of Arts Research and Education 18, no. 1 (2018): 39-44.
} 
increased sense of freedom. As we will show, we used this freedom of form and tonality throughout the collaborative composition process. We based ourselves on sets of elements (e.g., instruments, texture, concepts) and their respective choice of entry as the main criteria to perform.

\section{Creativity and Collaborative Music Composition}

In a general sense, creating comes from using different resources to form something that was not there before. The ability needed to reorganize previous knowledge towards a unique and original contribution is considered amongst the highest of cognitive functions. ${ }^{5}$ The mysticism formerly attributed to creativity has now been explained through multiple psychological research approaches, including psychometric testing, cognitive studies, and sociocultural methods. ${ }^{6}$ In music, the study of creativity has focused primarily on artistic works or the individual characteristics of musicians. ${ }^{7}$ Although rich information can be derived from such studies, they fail to address the lived experiences of composers and musicians during collaborative musical creation. We will provide insight into the collaborative experience by showing how we, as members of the Musical Learning Community, responded creatively under the strains of the COVID-19 pandemic.

To do this, we needed to see beyond the explanations of individual creativity and focus on what was known about group creativity. Despite the complexity of processes that may occur in a group setting, constructive interactions among group members are fundamental for collaboration and teamwork. ${ }^{8}$ How, then, were we able to foster the necessary actions to create together through virtuality amidst a global pandemic?

There is evidence that synchronous and asynchronous interactions can work as methods for collaborative composition in virtual platforms. ${ }^{9}$ Interactions of this nature involve sharing links to musical influences, planning virtual exploratory music-making sessions, discussing material worth preserving, resolving technical problems, and sharing the musicians' feelings. ${ }^{10}$ From our previous experiences, we noted that synchronous music-making software has many limitations and relies on each participant having access to a stable internet connection, which is not always possible. A more common approach is often for a leading composer to take the initiative to create complete musical drafts, which are then recorded and shared with other members who provide feedback. Musicians then record a previously established part with enough leeway to add some interpretative

\footnotetext{
${ }^{5}$ Lorin Anderson and David Krathwohl, A Taxonomy for Learning, Teaching, and Assessing: A Revision of Bloom's Taxonomy of Educational Objectives (New York: Longman, 2001), 84-86.

${ }^{6}$ Robert Sternberg, Handbook of Creativity (Cambridge: Cambridge University Press, 2002), 3-15.

${ }^{7}$ Adrian North and David Hargreaves, The Social and Applied Psychology of Music (Oxford: Oxford University Press, 2010), 14-22.

${ }^{8}$ Keith Sawyer, Group Creativity: Music, Theater, Collaboration (Mahwah: Lawrence Erlbaum Associates, 2003), 119-137.

${ }^{9}$ Michele Biasutti “Strategies Adopted During Collaborative Online Music Composition," International Journal of Music Education 36, no. 3 (November 2016): 473-90, https://doi.org/10.1177/0255761417741520.

10 lbid.
} 
variations. However, this approach creates many constraints for composers and musicians who lose out on the benefits of synchronous exploration.

\section{The Musical Totem: A Collaborative Methodology to Explore Musical Creativity}

Our creative inquiry for this project relied on both synchronous and asynchronous interactions and was conceived as a two-component investigation. On one side, there was the musical creation process, from which we derived a collaborative composition methodology. On the other side, we participated in reflective inquiry to shed light on the experiences of each musician as it related to the musical composition process and to investigate the deeper qualities of our artistic actions. Thus, we combined arts-based and autoethnographic approaches throughout the project.

\section{Collaborative Autoethnography}

Considering we intended to study ourselves as we underwent a collaborative composition process, we used an autoethnographic method. Ethnography is an anthropological method used to explore other cultures; ${ }^{11}$ thus, autoethnography refers to looking at the self as if it were the other to facilitate one's understanding of themselves. ${ }^{12}$ In this case, our perceptions of the compositional process were the focus of study. Studying the self requires increased reflexivity as humans are complex networks of interrelated layers. This means we needed to become aware of the reciprocal influence our actions and perceptions had on the compositional process. ${ }^{13}$ To achieve such reflexivity, we used the autoethnographic method of auto-interviewing. ${ }^{14}$ We brainstormed together potential questions and then refined an interview guide. Each one of us received the questions and was asked to complete the questions in written form right after finishing the music composition process.

Then, data were analyzed through a qualitative coding technique that allowed us to create a shared narrative. ${ }^{15}$ For this coding process, we imported the responses into a data analysis software (NVivo 12), categorized them by question, and extracted the meaning of each sentence in short phrases in order to capture the most salient characteristics of the text. These codes were then turned into a connected narrative form through a shared interpretation.

This research technique required an examination of our self-awareness, as we had to be cognizant of our own emotions and cultural codes. In this case, the geographical distancing, enhanced by the

\footnotetext{
${ }^{11}$ Frederick Erickson, "A History of Qualitative Inquiry in Social and Educational Research," in The Sage Handbook of Qualitative Inquiry, eds. Norman Denzin and Yvonna Lincoln (California: Sage Publications, 2018), 3844.

12 Sherick Hughes and Julie Pennington, Autoethnography: Process, Product, and Possibility for Critical Social Research (California: Sage Publications, 2017), 15-16.

13 Ibid. 92-93.

${ }^{14} \mathrm{Ibid}$. 65-66. We included the original guidelines in Appendix A, which include the interview protocol.

15 Johnny Saldaña, The Coding Manual for Qualitative Researchers (London: Sage Publications, 2016).
} 
pandemic, and the fact that four musicians responded to a shared phenomenon, makes this work take the form of a collaborative autoethnography. ${ }^{16}$

\section{Arts-Based Research}

Our music composition process was explorative. We sought to further understand ourselves through the lens of the arts as a way of knowing. ${ }^{17}$ It was an emergent and unpredictable process from its conception to its finalizing moments. The use of the arts as methodological tools to reach profound self-knowledge has begun to be systematized as a style of inquiry known as arts-based research. ${ }^{18}$ In music, the combination of autoethnographic and arts-based techniques can take cyclical form. ${ }^{19}$ That is a process of creating-reflecting-creating. Our approach to collaborative composition was performed in cycles where each musician reflected on a concept, composed, performed, recorded music influenced by that concept, and reflected on the composition process as it related to the self and the selected concept. Then, the recorded audio was sent to the next musician, who underwent the same cycle, until every musician had a turn to experience such a process.

The knowledge created through this arts-based collaborative autoethnography gives voice to the personal discourse of each musician; it provides a close-up look at the unique experience that each of us had as composers and performers throughout the project. It can also offer the audience a "me too" experience where the reader or listener may identify with the emotions, struggles, and concepts elicited through the composition. ${ }^{20}$

\section{Artistic Research}

We also see our work through the lens of artistic research, which can be conceived in three identified types: research on the arts, research for the arts, and research in the arts. ${ }^{21}$ Research on the arts is an interpretative perspective where the artistic practice is the focus of study. ${ }^{22}$ In music, this includes research from disciplines like ethnomusicology, pedagogy, psychology, and music cognition. ${ }^{23}$ Research for the arts puts an instrumental perspective at the forefront. The goal is to

\footnotetext{
${ }^{16}$ Hughes and Pennington, Autoethnography: Process, Product, and Possibility for Critical Social Research. 18.

17 Patricia Leavy, Researh Design: Quantitative, Qualitative, Mixed Methods, Arts-Based, and Community-Based Participatory Research Approaches (New York: The Guilford Press, 2017), 3-22.

18 Patricia Leavy, Method Meets Art: Arts-Based Research Practice (New York: The Guilford Press, 2015), vii-xi.

19 Danny Bakan, "Music as Method," in Method Meets Art: Arts-Based Research Practice, ed. Patricia Leavy (California: Sage Publications, 2017), 121-47.

${ }^{20}$ Mine Doğantan-Dack, "The Art of Research in Live Music Performance," Music Performance Research 5, (2012): 40.

21 Ruben Lopez-Cano and Úrsula San Cristobal Opazo, "Investigación, Investigación Musical e Investigación Artística," Investigación Artística en Música (Conaculta: Barcelona, 2014). 40

22 Henk Borgdorff, "The Production of Knowledge in Artistic Research" in The Routledge Companion to Research in the Arts, eds. Michael Biggs, Henrik Karlsson and Stiftelsen Riksbankens Jubileumsfond (Abingdon: Routledge, 2010).

${ }^{23}$ Lopez-Cano and San Cristobal Opazo, Investigación Artística en Música, 40.
} 
conduct technical research that benefits artistic practice and delivers tools and material knowledge applicable to the artistic product and process. ${ }^{24}$

Although our collaborative composition methodology has elements of the artistic research types identified above, our work is best aligned with research in the arts. In this case, artistic practice is not only the result of the study but its methodological vehicle. As we will describe, the project unfolds in and through the acts of creating and performing. ${ }^{25}$ Furthermore, it involves artistic creation by a community of competent music artists. This type of research has become difficult to define because it is diverse and inapprehensible. ${ }^{26}$ In this way, the term 'artistic research' becomes an umbrella term that denotes research activities based on artistic knowledge and artistic appearance. ${ }^{27}$

\section{Creative and Conceptual Influences}

\section{Cadavre Exquis / Exquisite Corpse}

The cadavre exquis is a surrealist method by which a collective work is created following a sequence and using a set of rules. ${ }^{28}$ Usually, the final corpus takes the form of a text or an image. In this way, communal poetry or visual work can take shape. We used this artistic method, often conceived as a game, and applied it musically. Like Pierre Schneider analyzes in his essay Note on the Exquisite Corpse: "Cadavre exquis is an excellent illustration of the currently popular axiom that some wholes are qualitatively different from their component parts."29

According to Schneider, the French surrealist Georges Hugnet defined the procedure in the following way: ${ }^{30}$ Every member of a group writes a noun in a paper that is hidden from the others. The paper is then passed to the left while receiving another paper prepared in the same way from the right. Each piece of paper has to accomplish a complete circuit by the end of the game. Then, everyone adds an adjective or qualifying phrase. Finally, participants rotate the paper and proceed in the same way for the verb, the direct object, and the final adjective. In the end, the paper is unfolded, and the results read aloud, making sure there is grammatical agreement.

We struggled at the beginning in our preparation meetings to define how these rules should look like for music. Many ideas were fleshed out; we wrestled with trying to define measure signature,

\footnotetext{
24 Ibid. 41.

${ }^{25}$ Borgdorff, Research in the Arts.

${ }^{26}$ Lopez-Cano and San Cristobal Opazo, Investigación Artística en Música, 41, 43.

${ }^{27}$ Polifonia Third Cycle Working Group, 'Guide to Third Cycle Studies in Higher Music Education' (AEC Publications: Utrecht, 2007) 16.

${ }^{28}$ Pierre Schneider, "A Note on the Exquisite Corpse," Yale French Studies 2, (1948): 85.

29 Ibid.

30 Ibid.
} 
tonality, instrumentation and found no success. Considering the sequential layering of instruments would leave us with a denser texture than that of text, the image of totems started to form and was accepted by the group as a useful reference to set compositional parameters.

\section{Totems}

A totem is a cultural symbol that is rich in meaning and has symbolic relationships between the environment and humans. Examples can be found in cultures from every part of the world. ${ }^{31}$ While the word was originally derived from the Algonquian language by settlers of the $18^{\text {th }}$-century, ${ }^{32}$ the current meaning of the word refers to "an emblematic depiction of something (such as an animal, plant, or supernatural being) [which] gives a family or tribe its name and that often serves as a reminder of its ancestry." More broadly, the term is also used for "any thing or person having particular emblematic or symbolic importance." In the religious practice of totemism, the totem is thought to "interact with a given kin group or an individual and to serve as their emblem or symbol." ${ }^{33}$ For example, totem poles from the First Nations of the Pacific Northwest are primarily visual monuments that represent, commemorate and document "ancestry, histories, people, or events" using "symbolic and stylized human, animal, and supernatural forms." 34

A recent report from Australia entitled Indigenous Kinship with the Natural World in New South Wales identifies the problematic idea of a universal totemic worldview by stating that: "the term 'totem' has proved to be a blunt instrument. Far more subtlety is required, and... there is regional variation on this issue." 35 This rich and varied meaning of totems drew us to them as a starting place for the thematic selections. In its capacity to depict emblems of self and community, totems' conceptual and visual influence became the driving force in our composition process. The combination of the rule-setting protocol of the exquisite corpse, the use of music, and the profound cultural connection of totems led us to the conception and commemoration of the musical totem.

\footnotetext{
${ }^{31}$ Encyclopedia Britannica Online, Academic ed., s.v. "totemism," accessed May 10, 2021, https://www.britannica.com/topic/totemism-religion/Some-examples-of-totemism.

32 Merriam-Webster, s.v. "Totem" accessed May 10, 2021, https://www.merriamwebster.com/dictionary/totem.

33 Encyclopedia Britannica, "totemism."

34 "Totem Poles: What is a Totem Pole?," Indigenous Foundations, accessed May 8, 2021, https://indigenousfoundations.arts.ubc.ca/totem poles/; “René R. Gadacz, "Totem Pole” In The Canadian Encyclopedia, accessed May 8, 2021, https://www.thecanadianencyclopedia.ca/en/article/totem-pole.

35 Deborah Rose, Diana James, and Christine Watson. Indigenous kinship with the Natural World in New South Wales. Hurstville, Australia: NSW National Parks and Wildlife Service, 2003. https://www.environment.nsw.gov.au/research-and-publications/publications-search/indigenous-kinship-withthe-natural-world-in-new-south-wales.
} 


\section{Compositional Process}

\section{Concept Selection}

We relied on the conceptual influence of totems to guide our interpretative freedom. After finding limited success in setting parameters by focusing on technical and musical properties, we decided to choose an animal with personal significance as a reference for each musicians' composition and interpretation. We asked each other to select an animal and then identify its relationship and influence on the musical composition and the chosen instrument. We then used a question-guide (See Appendix A) to help us reflect and communicate the selection's motives and the musical relationships it conveyed.

\section{Layered Composition}

Our concept of the musical totem has many similarities to the procedure for the exquisite corpse. Each musician would randomly start, record, send the recording to the next musician to layer the composition, and so on. After an entire cycle is completed, the second musician starts. The process continues in this order until the first musician begins again. The idea was to keep rotating until everyone had the opportunity to begin a section (see Fig. 1). Going first is especially important because the composition starts with no reference to others, and so the first musician could take the piece in different ways by establishing many of the musical features that would constraint the rest. Unfortunately, our original exploration was conceived as linear in time rather than simultaneous, limiting our capacity to embark on what would have been at least a 16 -week process. We were able only to complete one section, which spanned a five-week process.

Figure 1. The original conception of the musical totem, modeled after exquisite corpse procedures.

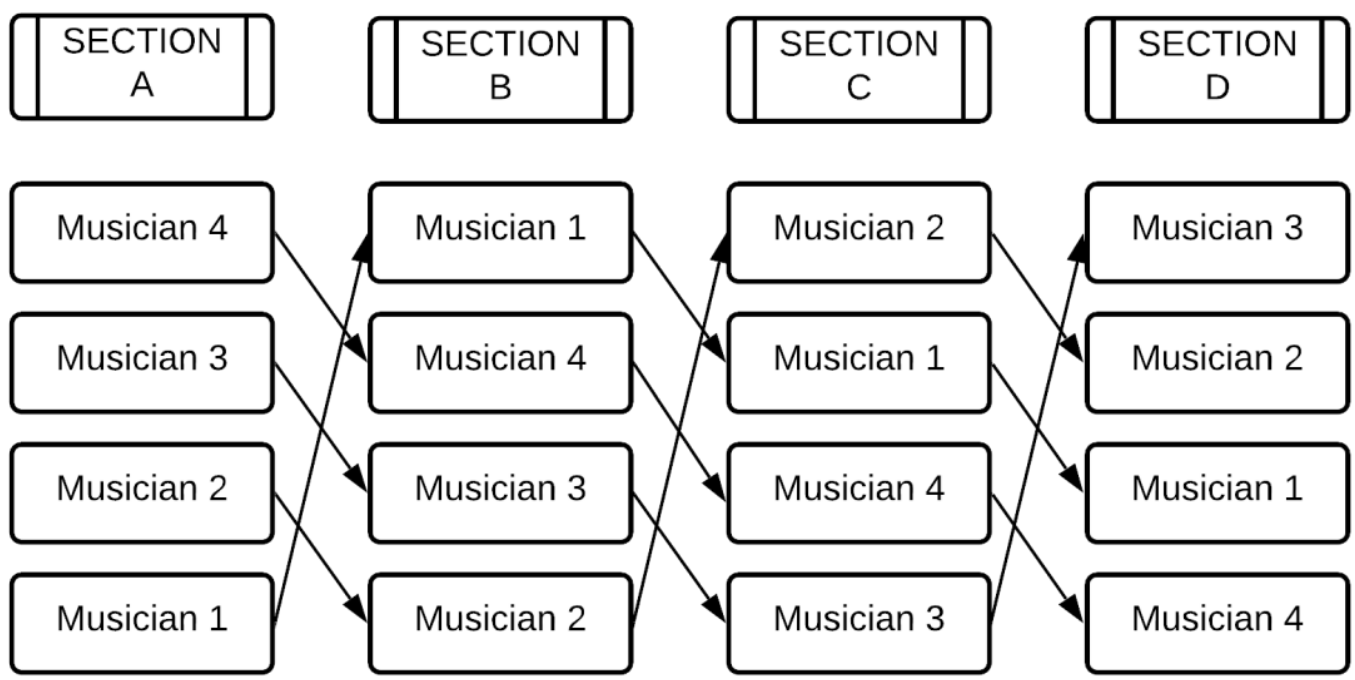


Most of us are comfortable with secondary instruments; however, we decided to limit our contributions to our primary instrument. Thus, our group of four included a drummer, a guitarist, a violinist, and a vocalist. Rather than randomly choose musician 1, we decided to proceed in a traditional "orchestral" order. Consequently, the drummer was selected as musician 1 , the guitarist as musician 2, the violinist as musician 3 , and the vocalist as musician 4.

\section{Reflections on the Process}

\section{Relationship between the Music and the Thematic Selection}

The four of us selected birds who inhabit the Andean region for the "concept selection" portion of this project. These independent decisions speak perhaps to the attachment to our native geography; such attachment to the land is likely something shared across cultures. ${ }^{36}$ Furthermore, the fact that no one selected mammals brings forth further questions about the musicans' decision process. Was it based on the drummer's selection, who began with a bird, and the rest felt compelled to proceed in the same direction? Answers to that question did not come out from the reflections. Instead, extramusical rationales converged in the artistic expression, including current life events. For example, David (musician 1) mentioned how the monotonic and rhythmic chant of the mochuelo andino (Glaucidium jardinii, see Fig. 2) promoted his interest in exploring a balance between melody and rhythm in the drumset. He also relied on the symbology of wisdom and protection, which he "found relevant to [his] current life events."

Each of us brought a different dimension of the habitat and actions of their selected bird into their musical expression. This was seen through the exploration of timbre and other possibilities the instruments allowed. While the drums had the intention to portray an improvisatory mutation of wind, space, mountains, and forest, the violin relied on experimental techniques to convey the contact of the bird with the wind using harmonics. Sofía (musician 3), the violinist, recorded two layers. The second layer was a melody meant to represent the hunting motions of the bird.

Sebastián (musician 2), who received the drum track, described his efforts with the guitar as a way to convey subtle and precise flight, characteristics of the halcón peregrino (Falco peregrinus, see Fig. 3). The inspiration was based on the heights and openness the bird seeks during flight. He reflected on how his motivation was the bird's capacity to take flight, its strength, and independence.

\footnotetext{
${ }^{36}$ Paul Morgan, "Towards a Developmental Theory of Place Attachment," Journal of Environmental Psychology 30, no. 1 (March 2010): 11-22, https://doi.org/10.1016/i.jenvp.2009.07.001.
} 
Figure 2. Glaucidium jardinii or pygmy owl (Photograph by Michael Woodruff) ${ }^{37}$

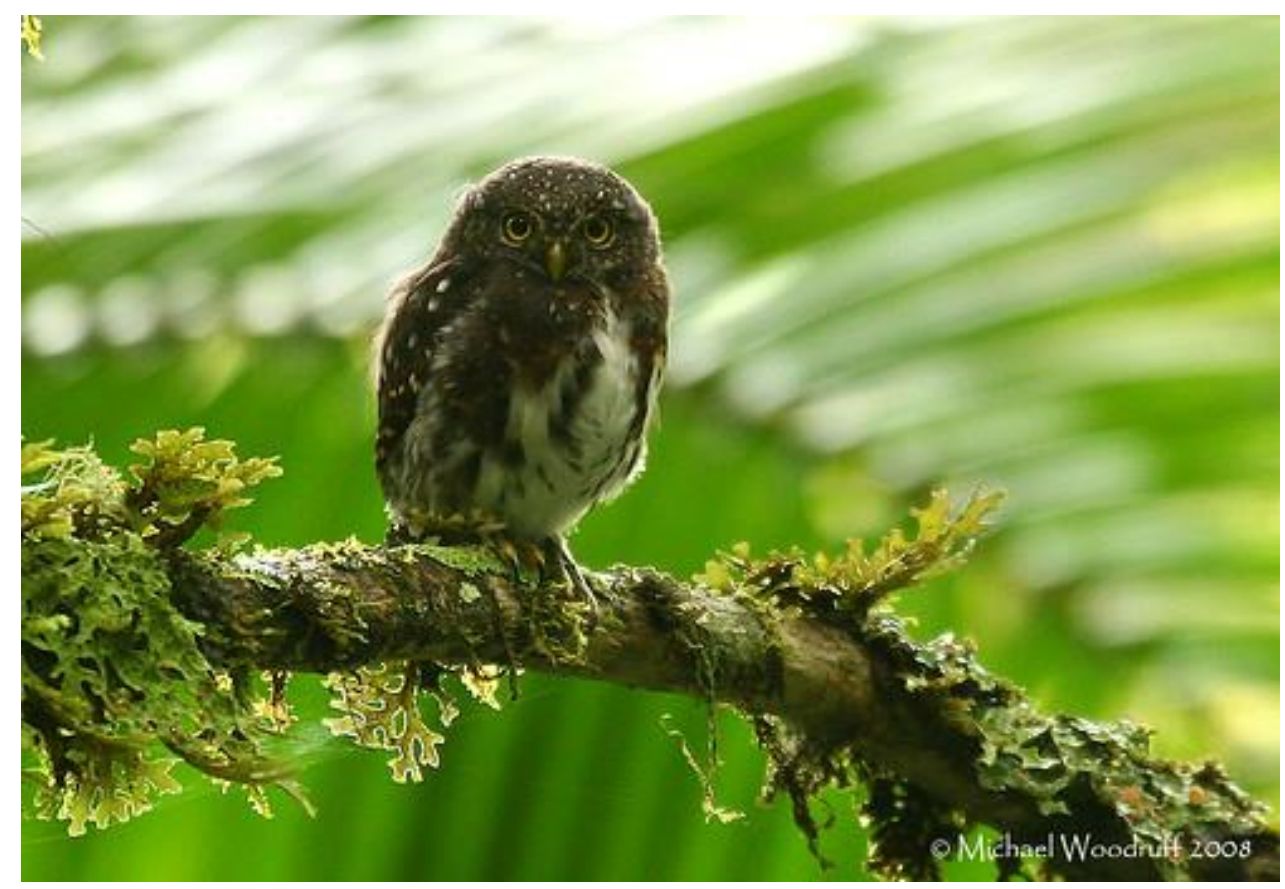

Figure 3. Falco peregrinus or peregrine falcon. (Photo by FurLined) ${ }^{38}$

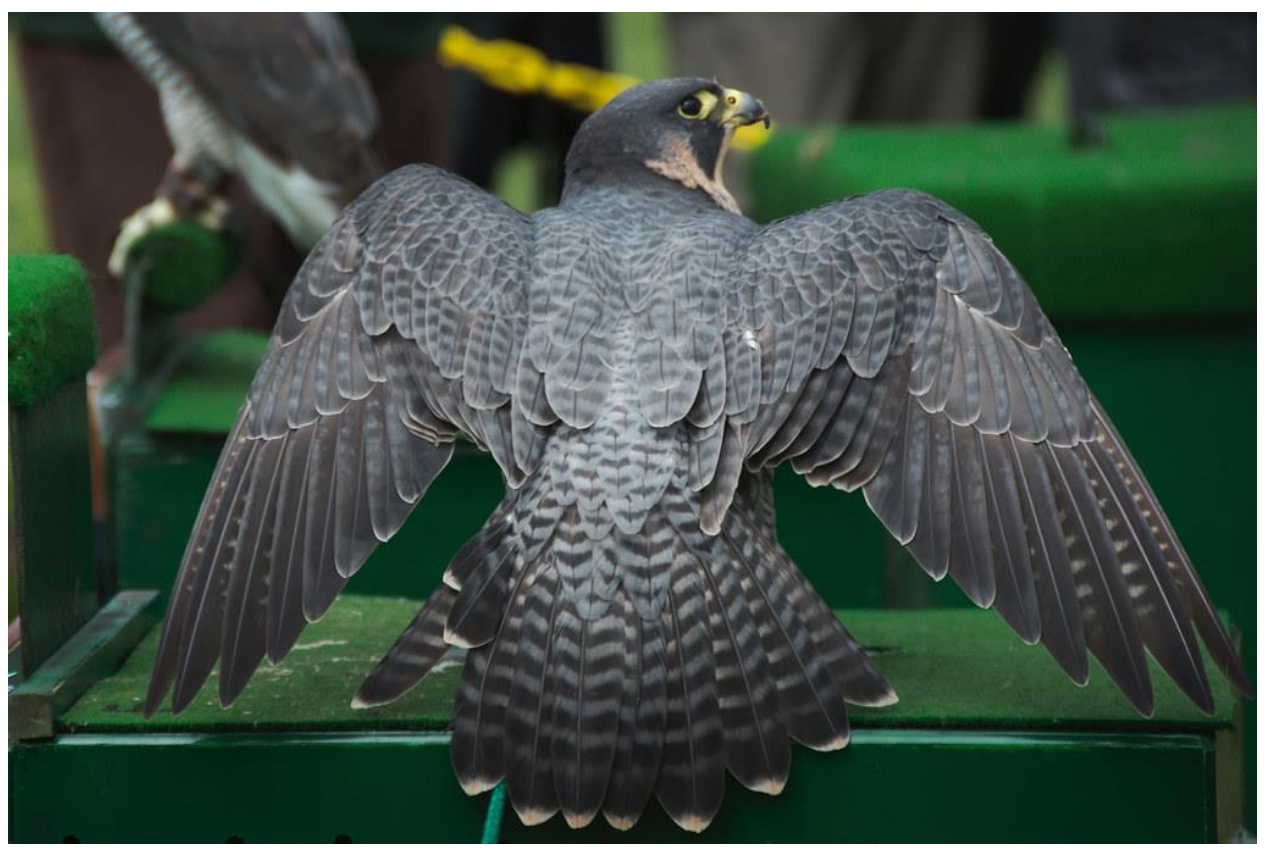

37 "Michael Woodruff: Costa Rican Pigm-Owl," Flickr, accessed May 16, 2021, https://www.flickr.com/photos/nightjar/2717918317/in/photostream/.

38 "Peregrine Falcon: FurLined," CC Search, accessed May 16, 2021, https://search.creativecommons.org/photos/9f9f6835-28dc-4197-92e2-deb459841160 
Finally, the vocalist chose to represent the Andean condor (Vultur gryphus, see Fig. 4), the national bird in many Andean countries. While growing up in Ecuador, we were continuously educated in how majestic the bird is and warned of its risk of extinction. ${ }^{39}$ These facts are so pervasive in our Andean cultures that the reasons ascribed to its selection corroborated it. It was mentioned that the majestic qualities, symbology, mythology, and Andean folklore were the reasons that drove the relationship with the bird. Musically, the vocalist reflected his task as needing to add a top layer that would be as powerful as the selection. He shared his process of listening to the sounds of the condor first to know what dimension of the bird to portray. As opposed to the instrumentalists, who relied on representation in their musical contributions, Víctor chose replication. The vocals of the condor were to be imitated through more aggressive vocal techniques. Some coherence was achieved in his replication, but like Sofía, he also added a melodic layer driven by a need to pierce through the musical textures. Knowing that the condor is among the largest flying birds in the world, ${ }^{40}$ the use of a high vocal range was mandatory. He further reflected on how once he heard the recording, it also brought him feelings of agony. Something that related with his experiences of seeing this bird in captivity, depressed, and unable to fly.

\section{Figure 4. Vultur gryphus or Andean condor. (Photo by Szeke) ${ }^{41}$}

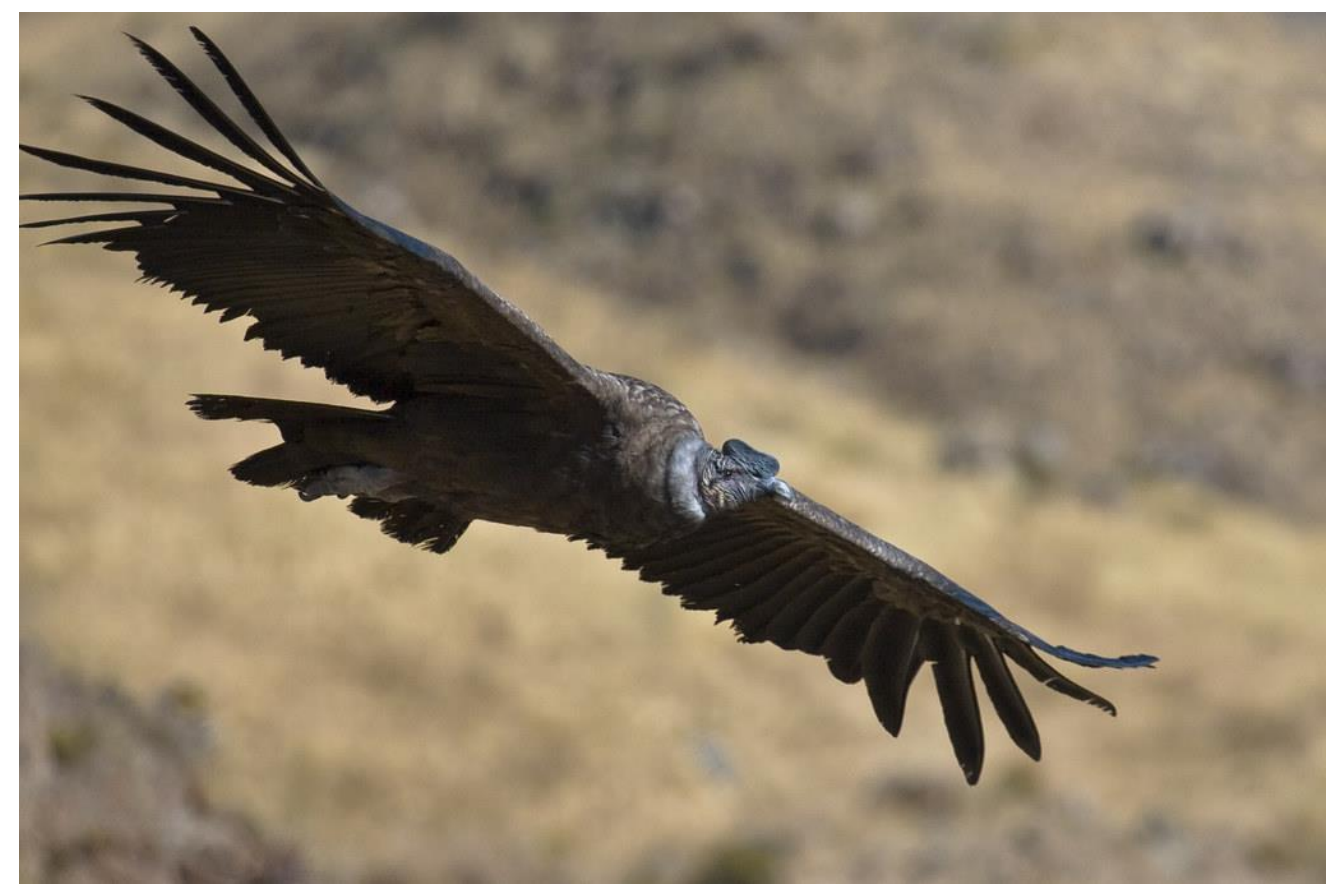

39 “Animals: Andean Condor," National Geographic, accessed May 8, 2021, https://www.nationalgeographic.com/animals/birds/facts/andean-condor.

40 lbid.

41 “Magnificent Andean Condor: Szeke," CC Search, accessed May 16, 2021, https://search.creativecommons.org/photos/7871e43d-5d39-4a9c-8b56-fbe391f045e9. 


\section{Freedom, Satisfaction, Frustration, and Concern while Creating}

Our sensations throughout the music creation process appeared to change as their musical possibilities became more constrained in their respective turns. For the drummer who started with a blank sound canvas, the experience was "very liberating, allowing [him] to connect with the sound, the exploration, and the creation." From a technical standpoint, he set parameters for himself to facilitate a flow experience. ${ }^{42}$ This means he actively created an opportunity to challenge himself while undergoing focused concentration to achieve an optimal performance state.

For the guitarist, who received no harmonic constraint, the experience was satisfactory as he saw the experimentation process as a way to develop his creativity. However, for the violinist and the vocalist, the sensations were different. Both recalled the struggles they faced while needing to find solutions to a preestablished problem. The process created some frustration and concerns about whether the two melodic textures would convey a coherent representation, despite the intrigue and curiosity the whole process created. We cannot know with certainty if the differences in experiences were a matter of the musicians' personalities, the harmonic constraints, or a combination of both.

\section{The Musical Totem, Music Information Professionals, and the Gratification in Music}

Despite the challenges we faced, there was a gratification of having undergone this process by the end. Those who went first displayed an eagerness and also uncertainty related to the outcome. It was interesting to note that, by the end of the recording, the vocalist felt an "ear fatigue," which led him to recall his experiences of long face-to-face rehearsals which happened before the pandemic. The musical experimentation, which moved us outside traditional parameters, liberated us through "el encato de crear" (the charm of creating), which was attributed to having undergone this musical experience.

This way of detailing processes and experiences can explain how musicians include personal and social perspectives. It can also shed some light on the motivations that drive musicians to keep composing despite adversities like a global pandemic. This paper takes into consideration how some musicians deal with contemporary environments and how they portray them. It also shows how technology both enabled and limited the musical creation and how the musicians balanced such tensions. It would be valuable to collect works of this nature from distinct time periods and locations to observe the variations in the creative and interpretative processes across cultural borders.

This collaborative composition methodology has value for musicians and music learners. It can help them challenge their creativity by trying new variations and versions of the process or by serving as

\footnotetext{
42 Susan O'Neill and Gary McPherson, "Motivation," in The Science and Psychology of Music Performance: Creative Strategies for Teaching and Learning, eds. Richard Parncutt and Gary McPherson, (New York: Oxford University Press, 2002), 35.
} 
a tool to resolve compositional needs when geographically distanced. Music information professionals, who may be working closely with musicians, music learners, and music educators, may also be interested in this process as an alternative practice to develop creativity and musicianship. It also speaks to the need to document compositional methods, which may help others learn from the documentation processes like the one we carried out. Beyond the instrumental or vocal ability, working in groups can serve as a bonding experience to create community, solidarity, and learning through creative musical explorations.

Video 1. The Musical Totem as conceived by the Musical Learning Community (Click Image to View) ${ }^{43}$

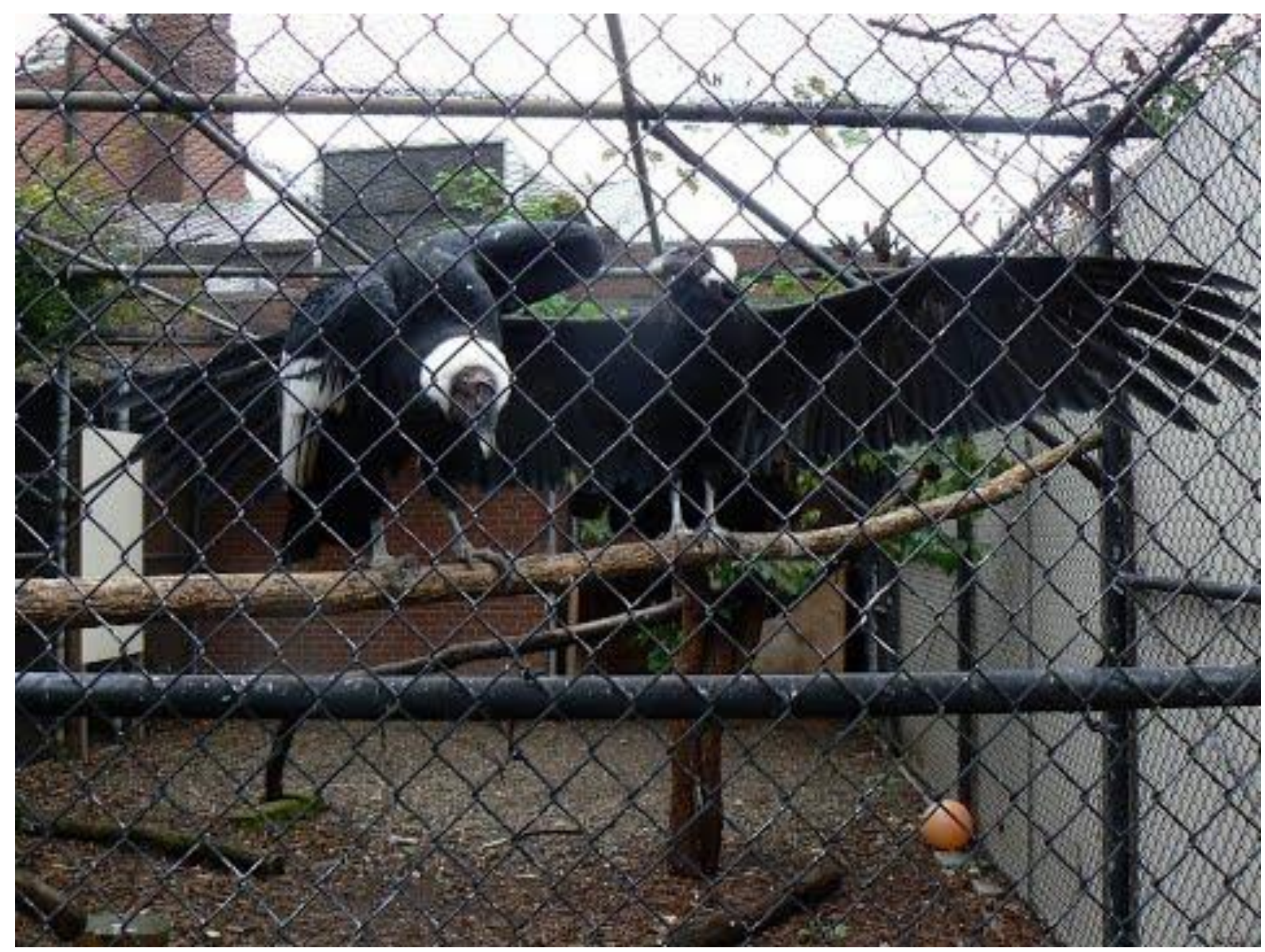

43 "Tótem Musical - Musical Totem (A Collaborative Music Composition Methodology): MLC Comunidad de Aprendiaje Musical," YouTube, accessed May 16, 2021, https://www.youtube.com/watch?v=r3yZFttYr2l. 


\section{Acknowledgment}

The Musical Learning Community thanks The Canadian Association of Music Libraries, Archives and Documentation Centres Review's Editorial Team for the opportunity to share our process and for being interested in documenting the impact of the COVID-19 pandemic on music-making and its dissemination, both from national and international music communities.

\section{Works cited}

Anderson, Lorin and David Krathwohl. A Taxonomy for Learning, Teaching, and Assessing: A Revision of Bloom's Taxonomy of Educational Objectives. New York: Longman, 2001.

Bakan, Danny. "Music as Method." In Method Meets Art: Arts-Based Research Practice, edited by Patricia Leavy. 121-47. California: Sage Publications, 2017.

Biasutti, Michelle. "Strategies Adopted During Collaborative Online Music Composition." International Journal of Music Education 36, no. 3 (November 2016): 473-90.

https://doi.org/10.1177/0255761417741520.

Borgdorff, Henk. "The Production of Knowledge in Artistic Research." In The Routledge Companion to Research in the Arts, edited by Michael Biggs, Henrik Karlsson and Stiftelsen Riksbankens Jubileumsfond. Abingdon: Routledge, 2010.

CAML Review. "Call for Contributions: Special Issue on the Impact of Covid-19 on Music Communities." Accessed May 6, 2021, https://www.caml-acbm.org/en/publication/.

Doğantan-Dack, Mine. "The Art of Research in Live Music Performance." Music Performance Research 5, (2012): 40.

Encyclopedia Britannica Online, Academic ed., s.v. "totmenism," accessed May 10, 2021, https://www.britannica.com/topic/totemism-religion/Some-examples-of-totemism.

Erickson, Frederick. "A History of Qualitative Inquiry in Social and Educational Research." In The Sage Handbook of Qualitative Inquiry, edited by Norman Denzin and Yvonna Lincoln, 38-44. California: Sage Publications, 2018.

Hughes, Sherick and Julie Pennington. Autoethnography: Process, Product, and Possibility for Critical Social Research. California: Sage Publications, 2017.

Indigenous Foundations. "Totem Poles: What is a Totem Pole?" Accessed May 8, 2021, https://indigenousfoundations.arts.ubc.ca/totem poles/.

Leavy, Patricia. Method Meets Art: Arts-Based Research Practice. New York: The Guilford Press, 2015. 
Leavy, Patricia. Research Design: Quantitative, Qualitative, Mixed Methods, Arts-Based, and Community-Based Participatory Research Approaches. New York: The Guilford Press, 2017.

Link, Martin. "Contemporary Music and Its Challenges for Music Theory." Harmonia: Journal of Arts Research and Education 18, no. 1 (2018): 39-44.

Lopez-Cano, Rubén and Úrsula San Cristóbal Opazo. "Investigación, Investigación Musical e Investigación Artística." Investigación Artística en Música. Conaculta: Barcelona, 2014.

Merriam-Webster, s.v. "Totem” accessed May 10, 2021, https://www.merriamwebster.com/dictionary/totem.

Morgan, Paul. "Towards a Developmental Theory of Place Attachment." Journal of Environmental Psychology 30, no. 1 (March 2010): 11-22, https://doi.org/10.1016/i.jenvp.2009.07.001.

National Geographic. “Animals: Andean Condor.” Accessed March 8, 2021. https://www.nationalgeographic.com/animals/birds/facts/andean-condor.

North, Adrian and David Hargreaves. The Social and Applied Psychology of Music. Oxford: Oxford University Press, 2010.

O'Neill, Susan and Gary McPherson. "Motivation." In The Science and Psychology of Music Performance: Creative Strategies for Teaching and Learning, edited by. Richard Parncutt and Gary McPherson, 35. New York: Oxford University Press, 2002.

Polifonia Third Cycle Working Group. 'Guide to Third Cycle Studies in Higher Music Education' . AEC Publications: Utrecht, 2007.

Rose, Deborah, Diana James, and Christine Watson. Indigenous kinship with the Natural World in New South Wales. Hurstville, Australia: NSW National Parks and Wildlife Service, 2003. https://www.environment.nsw.gov.au/research-and-publications/publicationssearch/indigenous-kinship-with-the-natural-world-in-new-south-wales.

Saldaña, Johnny. The Coding Manual for Qualitative Researchers. London: Sage Publications, 2016.

Sawyer, Keith. Group Creativity: Music, Theater, Collaboration. Mahwah: Lawrence Erlbaum Associates, 2003.

Schneider, Pierre. "A Note on the Exquisite Corpse." Yale French Studies 2, (1948): 85.

Sternberg, Robert. Handbook of Creativity. Cambridge: Cambridge University Press, 2002.

Gadacz, René R. "Totem Pole: Totem Pole Designs and Meanings." In The Canadian Encyclopedia. Accessed May 8, 2021, https://www.thecanadianencyclopedia.ca/en/article/totem-pole. 


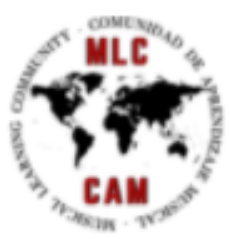

Lineamientos para la Creación del Tótem Musical

1. Selecciona un animal, ambiente, condiciones, que sean representativos de tu identidad en los momentos actuales.

2. Utiliza tu instrumento para plasmar tu selección de una forma musical (grabando el audio).

3. Escribe en un documento respuestas a las siguientes reflexiones:

a. ¿Cómo percibes que tu música describe tu selección?

b. ¿Cómo te sentiste en el proceso de creación?

c. ¿Cómo te sientes tras haber concluido tu parte?

d. ¿Qué razones ascribes a tu selección?

e. ¿Cómo crees que esta información le ayuda a un profesional de la información musical (e.g., coleccionistas de música, bibliotecarios de música, historiadores de música, etc.)?

4. Envía tu grabación de audio y escrito al correo electrónico mlc.cam arna@gmail.com

\begin{tabular}{|l|l|l|l|l|}
\hline $\begin{array}{l}\text { Semana 1 } \\
\text { Enero 11-17 }\end{array}$ & $\begin{array}{l}\text { Semana 2 } \\
\text { Enero 18-24 }\end{array}$ & $\begin{array}{l}\text { Semana 3 } \\
\text { Enero 25-31 }\end{array}$ & $\begin{array}{l}\text { Semana 4 } \\
\text { Febrero 1-7 }\end{array}$ & $\begin{array}{l}\text { Semana 5 } \\
\text { Febrero 8-14 }\end{array}$ \\
\hline David & Sebastián & Joshua & Sofía & Víctor \\
\hline
\end{tabular}

\section{Guidelines for the Creation of the Musical Totem}

1. Select an animal, environment, conditions, that are representative of your identity at the present time.

2. Use your instrument to translate your selection in a musical way.

3. Write in a document answers to the following reflections:

a. How do you perceive that your music describes your selection?

b. How did you feel about the creation process?

c. How do you feel after you've finished your part?

d. What reasons do you add to your selection?

e. How do you think this information helps a music information professional (e.g., music collectors, music librarians, music historians, etc.)?

4. Send your audio recording and text to the email mlc.cam.arna@gmail.com 